M.Denysenko, Doctor of Economic Sciences, professor, Professor of the Department of Economics and Services, Kyiv National University of Technologies and Design

ORCID ID: 0000-0001-8767-9762

O. Budiakova,

$P h D$ in Economics, Senior Lecturer of the Department of Economics and Services, Kyiv National University of Technologies and Design

ORCID ID: 0000-0001-6028-2650

DOI: $10.32702 / 2306-6806.2020 .10 .19$

\title{
FEATURES OF ECONOMIC DEVELOPMENT OF HOTEL AND RESTAURANT BUSINESS
}

\author{
М. П. Аенисенко, \\ А. е. н., професор, професор кафедри економіки та сфери обслуговування, \\ Київський національний університет технологій та дизайну \\ О. Ю. Будякова, \\ к. е. н., старший викдадач кафедри економіки та срери обслуговування, \\ Київський національний університет технологій та дизайну
}

\section{ОСОБАИВОСТІ ЕКОНОМІЧНОГО РОЗВИТКУ ГОТЕАЬНО-РЕСТОРАННОГО БІЗНЕСУ}

Currently in our country there is an intensive development of hotel and restaurant business. This process affects almost everyone, as consumers of these services are largely all residents and guests of the city and country. Modern life is impossible without rest in a cozy cafe and accommodation in a comfortable hotel. Employees of many companies and organizations use the services of restaurants, cafes, cafeterias during the working day, as well as hotel services when going on business trips or on vacation. In recent years, more and more people choose as a venue for banquets on the occasion of any solemn events restaurants of different levels and classes, as well as hotels to accommodate guests invited from other cities. Now everywhere there are new enterprises in this field, different in size and type of services provided. The development of the hotel and restaurant business is also important for the creation and modernization of the tourist infrastructure of the region. According to most researchers, the main factor hindering the development of inbound tourism in Ukraine is the lack of tourism and hospitality industry that meets modern international standards.

The article investigates that currently in our country there is an intensive development of hotel and restaurant business. This process affects almost everyone, as consumers of these services are largely all residents and guests of the city and country. Modern life is impossible without rest in a cozy cafe and accommodation in a comfortable hotel. Employees of many companies and organizations use the services of restaurants, cafes, cafeterias during the working day, as well as hotel services when going on business trips or on vacation. In recent years, more and more people choose as a venue for banquets on the occasion of any solemn events restaurants of different levels and classes, as well as hotels to accommodate guests invited from other cities. Now everywhere there are new enterprises in this field, different in size and type of services provided. The development of the hotel and restaurant business is also important for the creation and modernization of the tourist infrastructure of the region. According to most researchers, the main factor hindering the development of inbound tourism in Ukraine is the lack of tourism and hospitality industry that meets modern international standards.

У статті досліджено, що нині в нашій країні спостерігається інтенсивний розвиток готельно-ресторанного бізнесу. Цей процес зачіпає майже кожного, оскільки споживачами цих послуг значною мірою є всі жителі та гості міста та країни. Сучасне життя неможливе без відпочинку в затишному кафе та проживання в комфортабельному готелі. Співробітники багатьох підприемСтв й організацій користуютьСя послугами ресторанів, кафе, буфетів під час робочого дня, а також послугами готелів піА час виїзду в робочі відрядження або на відпочинок. В останні роки все більша кількість людей вибирає в якості місця проведення банкетів 3 нагоди будь-яких урочистих заходів ресторани різного рівня та кАасу, а також готелі, Ая заселення гостей, запрошених з інших міст. Зараз всюди з'являються нові підприємства такої 
сфери різні як за розміром, так й по виду послуг, що надаються. Розвиток готельно-ресторанного бізнесу також має велике значення, АЯ створення та модернізації туристичної інфраструктури регіону. На думку більшості дослідників, основним чинником, що стримує розвиток в '̈зного туризму в Україні, відсутність індустрії туризму та гостинності, що відповідає сучасним міЖнародним Стандартам.

Зараз на ринку готельно-ресторанних послуг Украйни виникАа реальна конкуренція, а СПоживач Став більш досвід ченим, що поставило перед підприємствами цієї сфери посл уг цілий ряд нових завдань, як-от: необхідність підвищення ефективності виробництва, зміцнення конкурентної позиції, а це неминуче пов'язане з впровадженням У повсякденну практику ведення бізнесу сучасних, осягнень менеджменту та маркетингу. Україна має всі можливості для успішного розвитку готельно-ресторанного господарства. Найбагатша історія України, рідкісні історичні пам'ятники, самобутня культура, політична Стабільність, відносна відкритість та ї̈ готовність до співпраці-все це спонукає до інтенсивного розвитку як туристичної, так й готельно-ресторанної сфери.

Останнім часом поряд з традиційними готелями та ресторанами почали з'являтися спеціалізовані підприємства зі скороченим набором послуг та справ, орієнтовані на обслуговування представників певного сегмента туристичного бізнесу. Оскільки послуги цієї галузі є невіА 'ємною частиною туристичного пакету, наявність різних підприємств, що надають якісні посл уги, вносить істотний внесок у формування іміджу міста (туристичного центру). Томунині є необхідність Удослідженні питань організації, управління та модернізації на підприємствах готельного-ресторанного бізнесу та особливостей економічного розвитку цієї сфери послуг.

Key words: hotels, restaurants, entrepreneurship in the botel and restaurant business, the service sector.

Ключові слова: готелі, ресторани, підприємничтво в готельно-ресторанному бізнесі, сфера обслуговування.

\section{FORMULATION OF THE PROBLEM}

Enterprise development planning is one of the most important elements of business structure management, the activity of which is characterized by a high level of innovation [1, p. 12], a high degree of risk and the ability to adapt to rapid changes in external conditions. But the peculiarities of the development of the hotel and restaurant business in Ukraine have not yet been sufficiently studied.

\section{ANALYSIS OF RECENT RESEARCH AND PUBLICATIONS}

The theoretical basis is the work of domestic and foreign scientists in the field of economics, tourism, tourism and related to the development of hotel and restaurant business: problems related to the functioning of hotels and hotel business were revealed in their works by such scientists as O. Davidova, L. Zavidna, V. Zaitseva, M. Malska, O. Lupich, H. Danko, N. Bilokin and others.

\section{PARTS OF THE GENERAL PROBLEM HAVE NOT BEEN SOLVED BEFORE}

The relevance and lack of strategic approaches to the development of hotel and restaurant business require that they become the object of special research, in which theoretical aspects would be combined with practical ones and would be aimed at improving the quality management of enterprises in the industry. Of particular importance is the proposal for hotel and restaurant businesses tools for developing strategies and assessing their cost-effectiveness.

\section{FORMULATION OF THE GOALS OF THE ARTICLE}

The purpose of the study is to develop theoretica provisions and practical recommendations for improving the activities of the hotel and restaurant business. To achieve this goal it is necessary to solve the following tasks: to define the concept and classify restaurants and hotels; consider the concept of quality management of enterprises; to analyze the quality of hotel and restaurant business service; identify ways to improve service in the hotel and restaurant business.

\section{PRESENTATION OF THE MAIN RESEARCH MATERIAL}

Many authors consider the term "hotel" as derived from the Latin "hospitalis", which means hospitable. There are other opinions about the origin of this concept today. One common view is that the English word "hospitality" comes from the Old French "hospice", which means "reception house". The oldest of its kind is the Hospice de Beaune in Burgundy, also known as Hotel Dieu. It was founded in 1443 as a charitable hospital and shelter for the poor. This hospital is still functioning. In the domestic practice of management, which has survived to this day, the word "hospitality" is associated primarily with the concept of "hospital", which means a military medical institution for inpatient treatment. From the point of view of common sense, there can be no question of any hospitality without meeting the basic human needs - the needs of food, rest and sleep. In this regard, the most reasonable and quite logical is the following definition of the hotel.

A hotel is a property complex that provides people outside the home with a range of services, the most important of which (complex-forming) is equally the service of accommodation and meals. This definition indicates the mandatory availability of two main services in the hotel accommodation and meals. In this case, their relationship can vary greatly. The content of the accommodation service is that, firstly, the use of special rooms (hotel rooms), and secondly, services are provided directly by the hotel staff: receptionist and reception of guests, maids for cleaning hotel rooms, etc. Hotel rooms are the main element of the accommodation service. These are multifunctional premises intended for rest, a dream, work of visitors. Due to the fact that hotel rooms are used by guests mainly in the evening and at night, their most important function is to provide sleep. The importance of other functions of hotel rooms primarily depends on the purpose of the hotel and the needs of guests. For example, in business hotels a very important function of the rooms is to provide the guest with the opportunity to work, ie there is a need for a desk, telephone, fax, computer, etc.

Hotels have different categories of rooms, which differ in area, furniture, equipment, facilities, etc. However, regardless of the category, each hotel room must have the following furniture and equipment: bed, chair or armchair per bed, bedside table or bedside table per bed, wardrobe, general lighting, trash can. In addition, each room must contain information about the hotel and an evacuation plan in case of fire. 


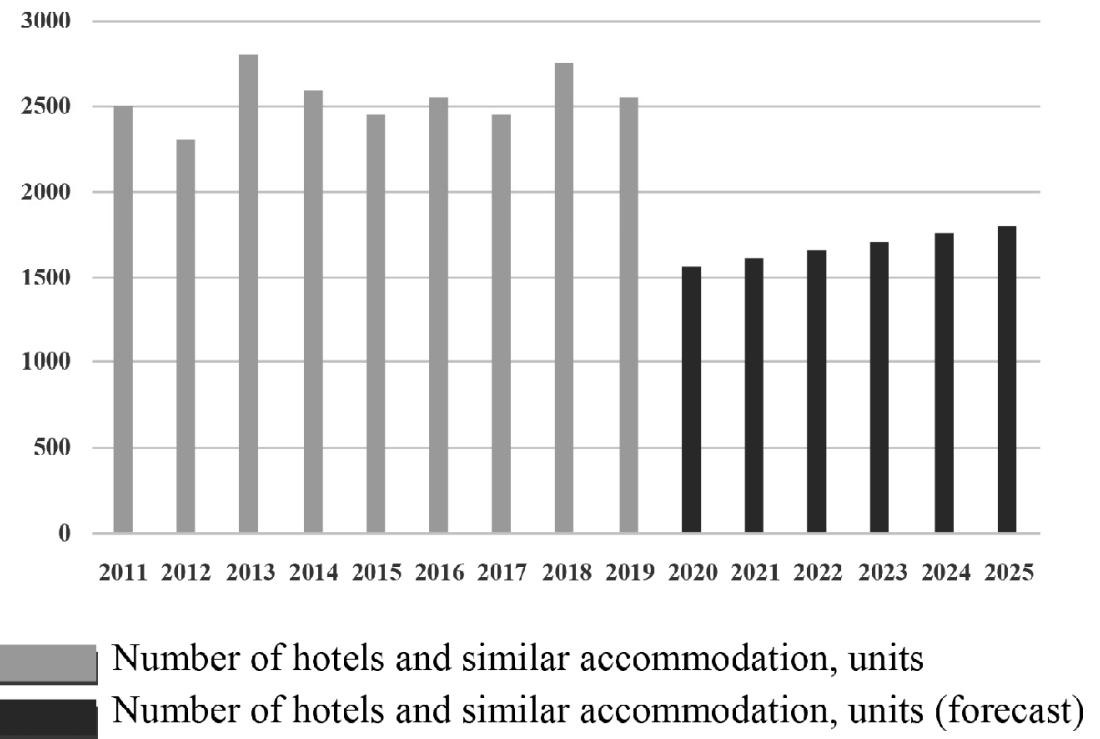

Fig. 1. Dynamics and forecast of the number of hotels and similar accommodation in Ukraine

Catering services consist of a combination of different processes: production (cooking in the kitchen), trade (sale of ready-to-eat products, alcoholic and soft drinks), service (serving guests by waiters in restaurants, bars, cafes, hotel rooms). Additional or other services include a swimming pool, sports, conference rooms, meeting rooms, car rental, dry cleaning, laundry, hairdresser, massage parlor and many others. Currently, additional services are becoming increasingly important in shaping the market attractiveness of the hotel and restaurant business. Remaining basic, the accommodation service is taken for granted by guests. Increased interest is the services that distinguish this hotel from others. In most cases, such services are additional. This is confirmed by the activities of many well-known hotel enterprises [2, p. 183]. For example, other services focused on providing opportunities to engage in various sports are in the first place in the complex of services of the German hotel chain "Robinson Club", which consists of 30 hotels. Hotels of the famous Swiss resorts ofDavos, Crans-Montana, before attracting highly paid professionals, bankers, politicians, provided the opportunity to hold international conferences, economic forums at the highest level, building and equipping conference rooms and a number of other facilities using the latest science and technology.

At the hotel company accommodation services, food and other services complement each other, in most cases are interdependent and are perceived by the guest as a whole $[3$, p. 125]. Taking into account how they are designed and combined into a single complex, a certain type of enterprise is formed. Due to the constant appearance on the hotel market of new services and forms of service, this typology is quite conditional. However, such a division is important for understanding the management of each type. Within these types, there are usually many varieties. The beginning of the hotel classification was laid at a time when there were very few establishments that are trustworthy. The classification was intended to provide safe and quality accommodation and meals for travelers. With the tremendous development of international tourism over the past 50 years, the hospitality industry has become mature, and the purpose of classification has shifted from consumer protection ideas (usually guaranteed by national regulations and legislation) to consumer information ideas. However, since November 30,1989, a document developed by the WTO in Madrid entitled "Interregional harmonization of hotel classification criteria based on classification standards approved by regional commissions" is in force, which is of a recommendatory nature. According to him, a hotel of any category must meet the requirements of safety and hygiene, provide round-the-clock service, emergency medical care, preservation of valuables, laundry, postal services. For hotels, classification is a way to provide consumers with the necessary information about the quality of service, infrastructure and other capabilities of the company, thus helping potential customers and demonstrating their loyalty to them. For consumers, classification means greater transparency, greater awareness and greater consistency in the evaluation of hotels.

The dynamics and forecasts of the number of hotels and similar accommodation in Ukraine are presented in Fig. 1 [4, p. 46].

The non-simultaneous processes of production and consumption of hotel services reflect their peculiarities. Regarding the complex of services provided in the hotel, such a general characteristic for the services as simultaneity, inseparable nature of the processes of production and consumption does not fully apply. Some hotel services are not related to the presence of the client. For example, cleaning and preparing a room for sale does not coincide with the place and time with the time of sale of the room in the reception service and direct check-in. Non-simultaneity characterizes food services: in most cases, cooking takes place in another place and at another time, different from the processes of serving and serving, which are carried out in part and in the presence of the client. For a hotel business, such a division of processes is a necessity. Direct service here must be preceded by the implementation of preparatory services designed to meet the demand for a certain moment. Limited storage capacity. The complex of hotel services as a whole cannot be saved for further sale. If the hotel room remains unsold for the current day, it cannot be sold additionally for this day. The same can be said for food services. Even if material services such as "food and beverages" to some extent (for the allowable period of implementation) can be stored, the service associated with their implementation will not be in demand and not paid. Urgent nature of hotel services. The specificity of hotel businesses is that service problems must be resolved quickly. This factor, along with the location is the most important when choosing a hotel. The time of providing a number of hotel services is measured even in seconds. Of the modern fastest service offers a hotel in Tokyo, where the maximum time required for registration at the arrival of the guest, payment, receipt of keys, etc., is limited to 45 seconds. Most other hotels have $10-15$ minutes to perform similar operations. Wide participation of personnel in the production process. An important feature of hotel services, which distinguishes them primarily from the services of industry, where more machines and machines are used, is the wide participation of people in the production process. 
Involvement of the human factor affects the heterogeneity, variability of quality and the associated lack of standardization, which is one of the most important problems in the development of hotel services. To solve this problem, many hotel companies are developing service standards - a set of manda tory rules for customer service, which are designed to guarantee the established level of quality of all operations. The standard defines the criteria by which the level of customer service and the activities of the staff of any service of the hotel business is assessed. Such criteria in most cases include the following:

- time to answer a call about information or booking $(15,20,30$ seconds);

- time of registration in the accommodation service. Regardless of the mass arrival, customers should not stand in line for more than the time set at a particular hotel company $(5,10,15$ minutes);

- time spent on providing a specific service. For example, luggage is delivered to the room no later than 3 minutes after check-in; laundry and cleaning of personal belongings are kept within a day, etc.;

- appearance and presence of a uniform. etc.

Knowledge of foreign languages by service personnel,

There are rules of conduct for hotel staff:

- The hotel employee must always be ready to provide customer service.

- The employee must show a positive attitude towards the guest: show respect, have a polite conversation, keep composure. contact.

- The employee must smile at the guest, maintain eye

- you need to be able to tactfully inform the guest and tell him even unpleasant news.

- No hotel employee has the right to argue with the guest, even over trifles. And if he does not really understand the desire of the guest, then politely ask.

- The guest's problems need to be solved quickly and urgently. The hotel employee should do everything possible to reassure the guest.

- Every employee must demonstrate confidence and competence.

- Hotel staff must practice 3-step service.

- Hotel staff must be responsible for the maximum level of cleanliness of the hotel. The hotel staff must adhere to the ethics of business communication, as business etiquette determines the relationship between the boss and subordinates, between employees within the institution and visitors.

This also includes the rules of using a business phone, the ability to conduct business correspondence. The relationship between the boss and subordinates largely determine the atmosphere in the team. First of all, the hotel manager must be respected by employees, be an authority for subordinates. This primarily affects hotel visitors. In order to have a friendly atmosphere in the team, which helps to better and faster to cope with the case, the leader must know and follow some rules:

- the manager must treat all employees equally;

- if there is a need to make remarks to the employee, it should not be expressed in the presence of other employees;

- go into the room with subordinates, the boss greets everyone, but the hand should not be extended;

- when meeting with the boss, subordinates should greet first, but if the boss is a young man, he is the first to greet a woman and a man much older than himself;

- manager - a man always passes a woman at the entrance to the elevator, on the stairs, helps to open the door;

- the leader must set specific tasks for the treatment and communication with subordinates;

If there is a situation when one of the employees is a close friend of the boss, then at work between them the relationship should be restrained and in the presence of others they should not have extraneous conversations [5; $6]$. There are also rules for official conversations of the chief with subordinates:

- the leader must make a plan of the conversation in advance;

- choose the time needed to achieve your goal;

- choose the place and time for interviews, taking into account their impact on the results;

- before starting a conversation, the boss needs to create an atmosphere of mutual trust;

- from the beginning to the end of the conversation, the leader must follow the main direction leading to the intended goal;

- the boss must be at the height of the position;

- the manager must stop the conversation after achieving the intended goal.

This is the ethics of business relations of the hotel and restaurant business. From the point of view of macroeconomics, hotel services are economic relations, the outcome of which depends more on world economic and national processes, relations, than internal causes. In this context, it is important to note that the development of the tourism sector at the global, national and regional levels is associated with the level of material and technical infrastructure of enterprises in the field of hotel and restaurant services [7, p. 462].

Without close interaction of the infrastructure of the tourist destination and the sphere of hotel services, further formation and realization of the tourist product is impossible $[8$, p. 473]. The development of the tourist region and tourist destination has a kind of multiplier effect on the hotel sector, as the growing number of tourists stimulates the hotel and restaurant industry, construction of hotel complexes and similar accommodation, and thus contributes to the development of the whole territory $[9$, p. 530; 10, p. 159]. In the current economic situation, tourism should be considered as an independent intersectoral complex of the national economy, as tourism, combining different sectors of the national economy, covers a horizontal space, including businesses of different industries.

\section{CONCLUSIONS}

The basis of the allocation of hotel services to a tourist destination as an independent, separate sector of the economy are the following circumstances:

- in the current economic situation, tourism should be considered as an independent intersectoral complex of the national economy, as the sphere of tourism, combining different sectors of the national economy, covers a horizontal space, including businesses of different industries.

- a set of institutions included in the hotel and restaurant sector, performing interconnected integrated functions;

- enterprises related to the hotel industry have a common resource potential;

- the set of enterprises in this area is similar in nature and at the same time affects other sectors of the national economy;

- the whole set of enterprises of the hotel sector is subject to uniform Rules and has a common localized management system.

Thus, in our concept, the sphere of hotel and restaurant services of a tourist destination is a system of integrated enterprises of different economic orientation, the purpose of which is to meet the needs of the population in hotel services with rational and efficient use of available resources.

Literature:

1. Аенисенко М.П., Будякова О.Ю. Підвищення індексу людського капіталу - важлива складова інноваційної кадрової політики підприємств. Економіка та держава. 2019. № 4. C. 11-17. DOI: 10.32702/23066806.2019.4.11 
2. Мельник А.О., Будякова О.Ю. Сучасні тенденції розвитку індустрії гостинності. Innovative development of hotel and restaurant industry and food production: proceedings of I International scientific and practical Internet conference / 24 April. Prague: Oktan-Print s.r.o., 2020. P. 182-183. DOI: 10.46489/OKPR-01

3. Melnyk A., Budiakova O.\& Mammadov I. Diagnostics of recreational and tourist systems. Transactions of pedagogical university. Series of mathematical and natural sciences, 2019. C. 67, № 3. С. 123-145.

4. Шевчук Ю. Сучасний стан та перспективи розвитку готельного бізнесу України: чинники та проблеми. Вісник КНУТА "Економічні науки". 2020. № 1 (143). C. $41-51$.

5.Аенисенко М.П., Будякова О.Ю. Сучасні стратегії управління персоналом підприємств. Приазовський економічний вісник. 2018. № 5 (10). С. 175-181. URL: http:/ /pev.kplu.zp.ua/vypusk-5-10

6. Аенисенко М.П. Кадрова політика як основа формування інноваційної стратегії управління персоналом підприємств / М.П. Аенисенко, О.Ю. Будякова // Вчені записки Університету "КРОК" (економічні науки). — № 4 (52). - 2018. - C. 231-238. - Режим доступу до реcypcy: http://snku.krok.edu.ua/index.php/vcheni-zapiskiuniversitetu-krok/article/view/137/156

7. Будякова О.Ю., Маммадов І.В. Економічні аспекти діагностики рекреаційно-туристичної системи. Матеріали XXVIII Міжнародній науковій конференції студентів і молодих учених "НАУКА І ВИЩА ОСВІТА", м. Запоріжжя, 13 листопада 2019 р. - Запоріжжя: КПУ, 2019. - C. 462-463.

8. Melnyk A., Budiakova O., Mammadov I. Economic aspects of the modern development of management of recreational and tourist systems. Матеріали VII Міжнародній науково-практичній заочній конференції "Формування ефективних механізмів державного управління та менеджменту в умовах сучасної економіки: теорія і практика", 29 листопада 2019 р. - Запоріжжя: КПУ, 2019. - С. $471-474$.

9. Будякова О.Ю. Особливості рекреаційно-туристичних територій. Адміністративно-територіальні vs економічно-просторові кордони регіонів: матеріали Міжнар. наук.-практ. -конф. (19-20 березня 2020 р.). K.: KHEУ, 2020. - 568 c. - C. $528-532$.

10. Будякова О.Ю. Основні аспекти мережевого бізнесу у туризмі України. Імперативи економічного зростання в контексті реалізації глобальних цілей сталого розвитку: тези доп. Міжнар. наук.-практ. Інтернет-конф. (м. Київ, 9 квітня 2020 р.). Київ: КНУТА, 2020. C. $158-160$.

\section{References:}

1. Denisenko, M.P. and Budiakova, O.Yu. (2019), "Enhancing human capital index - important complex of innovative personnel policy", Ekonomika ta derzhava, vol. 4, pp. 11-17. DOI: 10.32702/2306-6806.2019.4.11

2. Melnyk, A.O. and Budiakova, O.Yu. (2020), "Current trends in the hospitality industry", Innovative development of hotel and restaurant industry and food production: proceedings of I International scientific and practical Internet conference, Oktan-Print s.r.o., Prague, Czech Republic, 24 April, pp. 182-183. DOI: 10.46489/OKPR01

3. Melnyk, A.O. Budiakova, O.Yu. and Mammadov, I.V. (2019), "Diagnostics of recreational and tourist systems", Transactions of pedagogical university. Series of mathematical and natural sciences, vol. 67, no. 3, pp. 123-145.

4. Shevchuk, Yu. A. (2020), "Current state and prospects of hotel development in ukraine: critical factors and challenges", Visnyk KNUTD "Ekonomichni nauky", vol. 1 (143), pp. 41-51.

5. Denysenko, M.P. and Budiakova, O.Yu. (2018), "Modern enterprise management strategies", Pryazovskyi ekonomichnyi visnyk, vol. 5(10), pp. 175-181.
6. Denysenko, M.P. and Budiakova, O.Yu. (2018), "Personnel policy as the basis for the formation of an innovative strategy of personnel management of enterprises", Vcheni zapysky Universytetu "KROK" (ekonomichni nauky), vol. 4 (52), pp. 231-238.

7. Budiakova, O.Yu. and Mammadov, I.V. (2019), "Economic aspects of diagnostics of recreational and tourist system", Materialy XXVIII Mizhnarodnij naukovij konferentsii studentiv i molodykh uchenykh. NAUKA I VYSCHA OSVITA [Proceedings of the XXVIII International Scientific Conference of Students and Young Scientists, SCIENCE AND HIGHER EDUCATION], CPU, Zaporizhzhia, Ukraine, 13 November, pp. 462-463.

8. Melnyk, A.O. Budiakova, O.Yu. and Mammadov, I.V. (2019), "Economic aspects of the modern development of management of recreational and tourist systems", Materialy VII Mizhnarodnij naukovo-praktychnij zaochnij konferentsii. Formuvannia efektyvnykh mekhanizmiv derzhavnoho upravlinnia ta menedzhmentu $\mathrm{v}$ umovakh suchasnoi ekonomiky: teoriia i praktyka [Materials VII Mizhnarodnij naukovo-praktychnij zaochnij konferentsii, Formation of effective mechanisms of public administration and management in the modern economy: theory and practice], CPU, Zaporizhzhia, Ukraine, 29 November, pp. $471-474$.

9. Budiakova, O.Yu. (2020), "Features of recreational and tourist areas" Materialy Mizhnar. nauk.-prakt. -konf. Administratyvno-terytorial'ni vs ekonomichno-prostorovi kordony rehioniv [Materials of the International scientificpractical conference, Administrative-territorial vs economic-spatial borders of regions], KNEU, Kyiv, Ukraine, 19-20 March, pp. 528-532.

10. Budiakova, O.Yu. (2020), "The main aspects of network business in tourism of Ukraine", Tezy dopovidej Mizhnarodnoi naukovo-praktychnoi Internet-konferentsii. Imperatyvy ekonomichnoho zrostannia v konteksti realizatsii hlobal'nykh tsilej staloho rozvytku [Abstracts of the International Scientific and Practical Internet Conference, Imperatives of economic growth in the context of realization of global goals of sustainable development], KNUTD, Kyiv, Ukraine, 9 April, pp. 158-160.

Стаття надійила до редакиї 07.10.2020 p.

\section{www. dy.nayka.com.ua}

Електронне фахове видання

\section{ДЕРЖААВНЕЕ УУПРАВЛЛННЯ}

\section{Виходить 12 разів на рік}

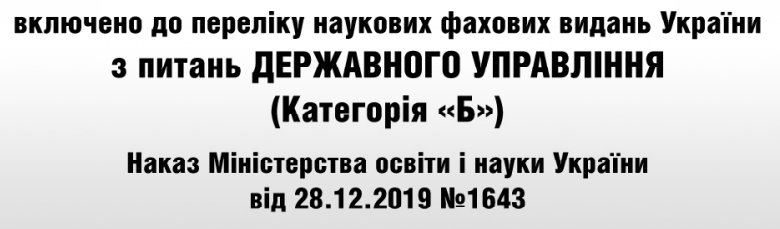

Спеціальність 281

e-mail: economy_2008@ukr.net

тел.: (044) 223-26-28, (044) 458-10-73 